and other factors, such as convenience, cost, time and appearance, were taken into account. By and large, waxing seems to have a slight advantage over steel wire brushing followed by 'Bedacryl'; coating with polyvinyl acetate and the graphite/'Bedacryl' treatment are also satisfactory.

\section{Education for Management}

ThE British Institute of Management has now published the second of the booklets dealing with education and training in the field of management. The first was concerned with the facilities available in technical colleges and other educational institutions, while the second describes short courses held at residential establishments and by professional and other bodies. These include courses for senior management organized at the Administrative Staff College and by the National Council of Y.M.C.A.'s ; courses for middle management and other supervisors arranged by certain professional and voluntary organizations, aduit education colleges, university departments and such bodies as the Hull Junior Chamber of Commerce ; courses for young workers, apprentices and other entrants to industry, organized mainly at residential educational colleges; courses for trade unionists organized mainly by the National Council of Labour Colleges; as well as courses in such topics as joint consultation, communications, work study and method engineering held at a variety of centres. The booklet also contains details of special courses arranged for education, training and personnel officers. The sponsors of the booklet are to be commended both for undertaking such an important work and for the succinctness and accuracy of their presentation.

\section{The Fourth Douglas Lea Memorial Lecture}

THe fourth Douglas Lea Memorial Lecture, entitled "Douglas Lea: Physicist into Biologist", will be delivered by Prof. C. A. Coulson, Rouse Ball professor of applied mathematics in the University of Oxford, at a meeting of the Hospital Physicists' Association on October 1 in the Reid-Knox Hall of the British Institute of Radiology, 32 Welbeck Street, London, W.1, at 8 p.m. The meeting is open to the public.

\section{Announcements}

THe eighth annual congress and festival of scientific films of the International Scientific Film Association will be held in Rome during November 6-12 at the University City and also at the National Research Council. Public performances of outstanding films of general appeal will be given, and specialized films will be shown and papers read at the meetings of the sections concerned with the film in medicine and veterinary science, in industry and technology, in scientific research, and in other subjects. Inquiries in Britain concerning the congress should be sent to the Scientific Film Association, 164 Shaftesbury Avenue, London, W.C.2. All other inquiries should be sent to the Segreteria VIII Congresso Internazionale della Cinematografia Scientifica, Commissione per la Cinematografia Scientifica del Consiglio Nazionale delle Ricerche, Piazzale delle Scienze 7, Roma.

THE fourth annual Eastern Joint Computer Conference and Exhibition, which is jointly sponsored by the American Institute of Electrical Engineers, the Institute of Radio Engineers and the Association for Computing Machinery, will be held in the Bellevue-Stratford Hotel, Philadelphia, Pa., during December 8-10, the theme this year being the "Design and Application of Small Digital Computers". Proceedings of the Conference will be published by the sponsoring societies and may be ordered from any one of them. The meeting will be open to all. Applications for registration should be sent to the Eastern Joint Computer Conference, P.O. Box 7825, Philadelphia 1, Pa.

THE Iron and Steel Institute, in association with the Institute of Metals, is organizing a symposium on powder metallurgy, to be held in Church House, Westminster, London, S.W.1, during December 1-2. Both ferrous and non-ferrous aspects of powder metallurgy will be considered, and there will be a small exhibition of components used in the various processes. The papers will be divided into three groups: metal powders and their assessment; research and production practice; and production and properties of engineering materials. The symposium will be open to all, whether or not they are members of either Institute, on application to the Secretary of the Iron and Steel Institute, 4 Grosvenor Gardens, London, S.W.1, from whom further information can be obtained.

The autumn conference of the Scientific and Technical Group of the Royal Photographic Society will be held this year on October 2 in the Lecture Theatre of the Stephenson Building, King's College, Newcastle upon Tyne, in conjunction with the University of Durham. The theme will be "The Scientific and Technical Applications of Photography", and, besides the reading of eight papers, visits will be made to the Departments of Naval Architecture, Physical Chemistry, and Photography of King's College. The conference will be open to all, no tickets being necessary. Further information can be obtained from Mr. C. J. Duncan, Director, Department of Photography, Medical School, Newcastle upon Tyne 1, or from the honorary conference secretary of the Scientific and Technical Group, Dr. R. S. Schultze, Research Library, Kodak, Ltd., Harrow, Middlesex.

The Edison Swan Electric Co., Ltd. (155 Charing Cross Road, London, W.C.2), has published the third in its series of educational booklets, entitled "Electrons", this latest one being on screened-grid and pentode valves. It surveys the disadvantages of the triode in order to show how, for certain purposes, improvement can be obtained by an additional grid as in the screened-grid or tetrode valve, and by two additional grids as in the pentode. In addition to explanatory circuit diagrams, the booklet contains a specially prepared sectional drawing of the Ediswan Mazda high-slope screened radio-frequency pentode $6 F 1$ valve, showing the electrode assembly and full details as to its operating conditions.

The "Bibliography of Articles appearing in Turkish Periodicals, No. 5" (pp. 138. Istanbul : Milli Egitim Basimevi), covering the period OctoberDecember 1952, contains some nine hundred entries, arranged according to the Universal Decimal Classification (first two figures only), and alphabetically by authors within each section. Slightly more than half the entries fall under science and applied science or technology. A list of periodicals covered, with the place of publication, and an author index are in. cluded, and the explanatory preface is in Turkish and in French. 